\section{Terakreditasi}

Ditjen Penguatan Riset dan Pengembangan, Kemenristekdikti

Keputusan No: 21/E/KPT/2018, Tanggal 9 Juli 2018
DOI: http://dx.doi.org/10.33772/jitro.v7i3.12150

http://ojs.uho.ac.id/index.php/peternakan-tropis

\title{
Bobot Badan dan Karakteristik Morfometrik Beberapa Galur Ayam Lokal
}

\author{
Asa Bela Sri Reformasi Nala Putri, Gushairiyanto' Depison* \\ ${ }^{1}$ Program Studi Peternakan Fakultas Peternakan Universitas Jambi \\ Jl. Raya Jambi - MA. Bulian KM 15 Mendalo Indah Jambi 36361 Indonesia \\ *Email korespondensi: depison.nasution@unja.ac.id
}

(Diterima 16-05-2019; disetujui 26-09-2020)

\begin{abstract}
ABSTRAK
Tujuan penelitian ini adalah untuk mengetahui bobot badan dan karakteristik morfometrik beberapa galur ayam lokal. Materi penelitian ini adalah ayam kampung super, ayam kampung unggul balitnak (KUB), dan ayam kampung masing-masing sebanyak 82 ekor. Data yang dihimpun adalah bobot badan, panjang paruh, lebar paruh, panjang kepala, lingkar kepala, tinggi kepala, panjang leher, lingkar leher, panjang sayap, panjang punggung, tinggi punggung, panjang dada, lebar dada, panjang shank, lingkar shank, panjang tibia, lingkar tibia, panjang jari ketiga dan jarak antara tulang pubis. Data bobot badan dan ukuran-ukuran tubuh dianalisis menggunakan uji-t sedangkan vektor nilai rata-rata ukuran-ukuran tubuh dianalisis dengan menggunakan uji $T^{2}$-Hotelling. Analisis komponen utama digunakan untuk mengidentifikasi penciri ukuran dan bentuk tubuh ayam lokal. Hasil penelitian menunjukkan bobot bahwa bobot badan ayam kampung Super $(837,98 \pm 68,97 \mathrm{~g})$ berbeda nyata dengan ayam KUB $(713,15 \pm 66,75 \mathrm{~g})$ dan ayam kampung $(605,53 \pm 80,01 \mathrm{~g})$. Secara umum ayam kampung super memiliki morfometrik yang relatif lebih tinggi daripada ayam KUB dan ayam kampung. Penciri ukuran tubuh ayam kampung super dan ayam KUB adalah panjang tibia, sedangkan ayam kampung adalah lebar dada. Penciri bentuk tubuh ayam kampung super adalah lebar dada, sedangkan ayam KUB dan ayam kampung adalah panjang punggung. Disimpulkan bahwa bobot badan dan morfometrik tertinggi ditemukan pada ayam kampung super, disusul ayam KUB dan ayam kampung. Ayam kampung Super dan ayam KUB memiliki penciri ukuran tubuh (panjang tibia) yang berbeda dengan ayam kampung (lebar dada). Ayam kampung super memiliki penciri bentuk tubuh (lebar dada) yang berbeda dengan ayam KUB dan ayam kampung (panjang punggung).
\end{abstract}

Kata Kunci: ayam lokal, bobot badan, karakteristk morfometrik

\begin{abstract}
This study aims to determine the bodyweight and morphometric characteristics of several local chicken strains. The research material were three strains of native chicken: kampong super chicken, kampung unggul balitnak (KUB) chicken, and kampung chicken, each strains consisted of 82 heads. Data collection on body weight and morphometric characteristics were performed at 2 months of age. Data collected includes: body weight and morphometric characteristics which include beak length, beak width, head length, head circumference, head height, neck length, neck circumference, wing length, back length, back height, chest length, chest width, shank length, shank circumference, tibia length, tibia circumference, third finger length and pubic bone distance. Data collected were analyzed using t-test to determine differences in body weight and body measurements between chicken strains. Average value vector of chicken body measurements was analyzed using $\mathrm{T}^{2}$-Hotelling statistical test. Principal component analysis statistical test was used to identify the shape and size characteristics of each chicken strain. Data processing was assisted by using Minitab statistical software version 18. Results of this study showed that kampong super chicken has best bodyweight and body weight gain among other strains. The identifier of body size and shape of kampong super chicken were tibia length and breast width. The identifier of body size and shape of KUB chicken were tibia length and back length, while the identifier of body size and shape of the kampung chicken were chest width and back length.
\end{abstract}

Keywords: body weight, native chicken, morphometric characteristic 


\section{PENDAHULUAN}

Ternak unggas merupakan salah satu sumber penghasil protein hewani yang cukup digemari oleh masyarakat Indonesia. Salah satu jenis ternak unggas yang dimanfaatkan sebagai bahan pangan adalah ternak ayam lokal. Beberapa faktor yang memberi kemudahan pemeliharaan ayam lokal antara lain tidak membutuhkan lahan yang luas, penyediaan pakan mudah dan murah sehingga lebih cepat dirasakan manfaat ekonominya, cepat beradaptasi terhadap lingkungan, tahan terhadap lingkungan yang buruk, serta lebih kebal terhadap penyakit dibandingkan dengan ayam ras. Beberapa galur ayam lokal Indonesia yang banyak dipelihara masyarakat adalah ayam kampung super, kampung super balitnak (KUB), dan ayam kampung.

Ayam kampung super merupakan hasil persilangan antara ayam kampung pejantan berpostur besar dan berkualitas baik dengan ayam betina ras petelur. Ayam ini memiliki pertumbuhan yang cepat dan produktivitas telur yang tinggi. Pada umur 2 bulan ayam kampung Super mampu mencapai bobot konsumsi 0,9-1,1 kg/ekor dan mulai bertelur pada umur 5 bulan (Ashar et al., 2016). Berdasarkan SK Menteri Pertanian nomor :274/Kpts/SR.120/2/2014 tentang Pelepasan Galur Ayam KUB-1 bahwa ayam KUB (kampung unggul balitnak) merupakan salah satu galur ayam hasil pemuliaan ayam kampung (Gallus-gallus domesticus) yang berasal dari daerah Cianjur, Depok, Majalengka, dan Bogor Provinsi Jawa Barat yang telah diseleksi selama 6 generasi yang mampu menghasilkan telur sebanyak 160-180 butir/tahun. Ayam ini dipelihara dengan tujuan sebagai penghasil telur tetas, telur konsumsi dan produksi daging. Ayam kampung adalah ayam lokal yang tidak memiliki karakteristik khusus. Masyarakat umumnya memelihara ayam kampung untuk mendapatkan daging, telur maupun sebagai tabungan. Bila dibandingkan dengan ayam ras, produktivitas beberapa galur ayam lokal tersebut masih tergolong rendah. Salah satu usaha untuk meningkatkan produktivitas ternak adalah melalui seleksi. Namun demikian, perlu dilakukan karakterisasi sebagai dasar untuk melakukan seleksi terhadap ayam lokal.

Karakterisasi merupakan langkah awal dalam pemuliabiakan ternak dalam rangka mengidentifikasi sifat-sifat penting yang bernilai ekonomis seperti bobot badan dan pertambahan bobot badan atau sifat-sifat penciri rumpun ternak yang bersangkutan. Karakterisasi ayam lokal dapat dilakukan dengan cara mengidentifikasi morfometrik. Morfometrik merupakan sifat kuantitatif yang dapat digunakan sebagai kriteria seleksi untuk meningkatkan produktivitas ayam lokal. Sifat kuantitatif ayam lokal berdasarkan morfometrik meliputi panjang badan, panjang leher, panjang sayap, lebar sayap, lingkar dada, lebar dada, panjang kepala, lebar kepala, panjang paruh, panjang jengger, tinggi jengger, panjang tulang tibia, panjang metatarsus, lingkar metatarsus, panjang jari terpanjang, panjang femur, panjang maxilla, panjang sternum, dan bobot badan (Ashifudin et al., 2017; Hummairah et al., 2016; Rangkuti et al., 2016). Variabel-variabel morfometrik tersebut dapat menjadi penciri ukuran dan bentuk tubuh ayam lokal yang berguna untuk memprediksi potensi produksi, peluang peningkatan produktivitas ternak, dan sebagai acuan standarisasi sifat-sifat ayam lokal secara lengkap seperti pada ayam kedu jengger merah dan jengger hitam generasi pertama (Ashifudin et al., 2017), ayam kampung di Kabupaten Batubara (Hummairah et al., 2016), dan ayam kampung di Labuhanbatu Selatan (Rangkuti et al., 2016)

Informasi mengenai sumberdaya genetik yang terkait dengan sifat-sifat ekonomi penting pada beberapa galur ayam lokal Indonesia belum banyak diketahui. Informasi ini sangat penting sebagai dasar acuan dalam upaya pengembangkan ayam lokal Indonesia ke depannya. Oleh karena itu, tujuan penelitian ini adalah untuk mengetahui bobot badan dan karakteristik morfometrik beberapa galur ayam lokal.

\section{MATERI DAN METODE}

Penelitian ini berlokasi di kandang Fakultas Peternakan Universitas Jambi yang dilaksanakan selama 2 bulan, mulai Juli sampai September 2019. Materi yang digunakan dalam penelitian ini adalah ayam kampung super, KUB dan ayam kampung sebanyak 82 ekor dari setiap galur, timbangan digital kapasitas $3 \mathrm{~kg}$ dengan ketelitian $0,1 \mathrm{~g}$ dan alat tulis. Metode yang digunakan adalah metode eksperimen. Ayam dipelihara mulai umur DOC sampai umur 2 bulan dalam kandang koloni yang diberi pakan komersial produksi PT. Japfa Comfeed (Tabel 1) dan air minum secara terusmenerus (ad libitum). Ukuran kandang yang digunakan adalah $4 \times 3 \times 1,8 \mathrm{~m}$ yang dilengkapi dengan tempat pakan, tempat minum serta lampu penerang. Pengambilan data bobot badan dan morfometrik dilakukan pada umur 2 bulan.

Data yang dihimpun adalah karakteristik morfometrik meliputi: bobot badan (BB), pertambahan bobot badan (PBB), panjang paruh 
(PP), lebar paruh (LP), panjang kepala (PK), lingkar kepala (LK), tinggi kepala (TK), panjang leher (PL), lingkar leher (LL), panjang sayap (PSa), panjang punggung $(\mathrm{PPu})$, tinggi punggung $(\mathrm{TPu})$, panjang dada (PD), lebar dada (LD), panjang shank (PS), lingkar shank (LS), panjang tibia (PTi), lingkar tibia (LTi), panjang jari ketiga (PJK), dan jarak antara tulang pubis (JTP).

1. Bobot Badan (BB) diukur dengan cara menimbang ayam dengan timbangan digital $(\mathrm{g})$.

2. Panjang Paruh (PP) merupakan jarak antara pangkal maxilla sampai ujung maxilla, diukur menggunakan jangka sorong digital (mm) (Sartika, 2013; Suhardi, 2012).

3. Lebar Paruh (LP) diukur dari pinggir paruh bagian luar sebelah kiri dan kanan, dengan menggunakan jangka sorong digital (mm).

4. Panjang kepala (PK) diukur dari pangkal paruh hingga kepala bagian belakang, menggunakan jangka sorong digital (mm).

5. Lingkar kepala (LK) diukur pada bagian kepala yang paling tinggi dengan melingkarkan pita ukur ( $\mathrm{cm}$ dikonversikan ke $\mathrm{mm})$.

6. Tinggi Kepala (TK) diukur pada bagian kepala yang paling tinggi dengan menggunakan jangka sorong digital (mm).

7. Panjang Leher (PL) diukur dari tulang first cervical vetebrae sampai dengan last cervical vetebrae menggunakan jangka sorong digital (mm).

8. Lingkar Leher (LL) diukur dengan melingkarkan pita ukur dileher $(\mathrm{cm}$ dikonversikan ke mm).

9. Panjang Sayap (PSa) diukur dari tulang humerus sampai ujung phalanges menggunakan pita ukur (cm di konversikan ke mm) (Permadi et al., 2020).

10. Panjang Punggung ( $\mathrm{PPu}$ ) diukur dari pangkal leher sampai pangkal ekor menggunakan pita ukur (cm di konversikan ke mm).

11. Tinggi Punggung (TPu) diukur dari bagian bawah ayam berpijak sampai punggung menggunakan penggaris ( $\mathrm{cm}$ di konversikan ke $\mathrm{mm})$.

12. Panjang Dada (PD) atau sternum dilakukan dari ujung dada bagian depan sampai ujung bagian belakang menggunakan jangka sorong (mm) (Permadi et al., 2020).

13. Lebar Dada (LD) diperoleh dengan mengukur jarak dari tulang sternum bagian kiri hingga bagian kanan (yang paling lebar) menggunakan jangka sorong digital (mm).
14. Panjang Shank (PS) diukur sepanjang tulang tarsometatarsus (shank) menggunakan jangka sorong digital (mm) (Permadi et al., 2020).

15. Lingkar Shank (LS) diukur dengan melingkarkan pita ukur pada bagian tengah tulang tarsometatarsus (shank) (cm di konversikan ke mm). (Sartika, 2013; Suhardi, 2012).

16. Panjang Tibia (PTi) diukur dari patella sampai ujung tibia diukur dengan menggunakan jangka sorong digital (mm). (Sartika, 2013; Suhardi, 2012).

17. Lingkar Tibia (LTi) diukur dengan melingkarkan pita ukur pada tibia ( $\mathrm{cm}$ di konversikan ke mm).

18. Panjang Jari Ketiga (PJK) diukur dari pangkal sampai ujung jari ketiga di ukur menggunakan jangka sorong digital (mm) (Permadi et al., 2020).

19. Jarak antara Tulang Pubis (JTP) diukur menggunakan jangka sorong digital (mm).

Data yang dikumpulkan meliputi bobot badan dan ukuran-ukuran tubuh kemudian dikelompokkan berdasarkan jenis kelamin dan galur. Selanjutnya data akan dianalisis secara deskriptif untuk mendapatkan data rataan, simpangan baku, dan koefisien keragaman

Rataan yaitu nilai yang digunakan untuk mewakili sekumpulan data, rumus yang digunakan yaitu sebagai berikut:

$$
\bar{x}=\frac{1}{n} \sum_{i=1}^{n} x_{i}
$$

Selanjutnya untuk mencari nilai simpangan baku maka menggunakan rumus:

$$
s=\sqrt{\frac{1}{n-1} \sum_{i=1}^{n}\left(x_{i}-\bar{x}\right)^{2}}
$$

Koefisien keragaman dihitung dengan rumus sebagai berikut:

$$
K V=\frac{s}{\bar{x}}
$$

Keterangan :

$x^{-}=$nilai rataan

$\mathrm{s}=$ simpangan baku

$\mathrm{KV}=$ koefisien keragaman

Data kemudian dikoreksi dari betina ke jantan, hal ini bertujuan untuk menghilangkan salah satu faktor pembeda antar sampel yaitu data jenis kelamin. Data hasil koreksi tersebut akan digabungkan dengan data pejantan, sehingga parameter yang dibandingkan pada sampel penelitian ini hanya data antar galur ayam, dan data 
ini hanya digunakan pada analisis komponen utama. Rumus yang digunakan untuk koreksi data mengikuti penelitian Depison (2010):

$$
\begin{aligned}
& \mathrm{R}=\quad \frac{\bar{x} \mathrm{i}}{\bar{x} \overline{\mathrm{j}}} \\
& \mathrm{K}=\mathrm{R} \text {. }\left(\mathrm{X}_{1.1 \mathrm{j}}, \mathrm{X}_{1.2 \mathrm{j}}, \ldots \mathrm{X}_{\mathrm{n} . \mathrm{nj}}\right) \\
& \text { Keterangan: } \\
& \mathrm{R} \quad=\text { rataan antar jenis kelamin } \\
& \bar{x} \overline{\mathrm{i}}=\text { rataan pada data jantan } \\
& \bar{x} \overline{\mathrm{j}}=\text { rataan pada data betina } \\
& \mathrm{K}=\text { Koreksi } \\
& \mathrm{X}_{1.1 \mathrm{j}} \quad \text { = data baris pertama pada kolom pertama sapi }
\end{aligned}
$$

Selanjutnya data dianalisis dengan menggunakan uji beda rata-rata (uji-t). Vektor nilai rata-rata ukuran-ukuran tubuh dianalisis menggunakan uji statistik $T^{2}$-Hotelling. Kemudian dilakukan uji statistik untuk mengidentifikasi variabel penciri bentuk dan ukuran tubuh pada ayam kampung super, KUB dan ayam kampung menggunakan analisis komponen utama (AKU) (Gaspersz, 2006). Pengolahan data dilakukan dengan menggunakan perangkat lunak statistika Minitab versi 18.

\section{HASIL DAN PEMBAHASAN}

Rataan bobot badan dan karakteristik morfometrik pada ayam kampung super, KUB dan ayam kampung disajikan pada Tabel 1.

Tabel 1. Kandungan nutrisi jenis pakan komersial

\begin{tabular}{lcc}
\hline Kandungan Nutrisi & BR 1 & BR 2 \\
\hline Protein Kasar (\%) & $20,0-22,0$ & $18,0-20,0$ \\
Lemak Kasar (\%) & $5.0-7,0$ & $5,0-7,0$ \\
Serat Kasar (\%) & $3,0-5,0$ & $3,0-5,0$ \\
Abu (\%) & $5,0-7,0$ & $5,0-7,0$ \\
Ca (\%) & $0,9-1,1$ & $0,9-1,1$ \\
Phosphor (\%) & $0,6-0,8$ & $0,6-0,8$ \\
ME (kkal) & $2900-3100$ & $3000-3200$ \\
\hline
\end{tabular}

\section{Bobot Badan}

Pada Tabel 1 terlihat bahwa bobot badan ayam kampung super, KUB, dan ayam kampung yaitu masing-masing sebesar 837,98 $\pm 68,97$; $713,15 \pm 66,75$; dan $605,53 \pm 80,01$ g. Hasil uji-t menunjukkan bobot badan ayam kampung super berbeda nyata $(\mathrm{P}<0,05)$ lebih tinggi daripada ayam KUB maupun ayam kampung. Demikian juga ayam KUB berbeda nyata $(\mathrm{P}<0,05)$ lebih tinggi daripada ayam kampung. Perbedaan bobot badan ini diduga disebabkan oleh faktor genetik karena pada penelitian ini semua ayam mendapat perlakukan lingkungan dan pakan yang sama. Hal ini sesuai dengan pendapat Djego et al. (2019) bahwa perbedaan bobot badan pada kelompok ternak yang diberikan pakan yang sama secara $a d-$ libitum disebabkan oleh faktor genetik.

Bobot badan ayam kampung super hasil penelitian ini lebih rendah dari bobot standar yang seharusnya dicapai yaitu $0,9-1,1 \mathrm{~kg}$ pada umur 2 bulan (Ashar et al., 2016), sedangkan bobot badan ayam KUB pada penelitian ini lebih tinggi dari laporan Urfa et al. (2017), bahwa bobot badan ayam KUB umur 2 bulan yaitu 512 g, sedangkan bobot badan ayam kampung pada penelitian lebih rendah dari penelitian Eriko et al. (2016) yang menyatakan bahwa bobot ayam kampung pada umur 8 minggu adalah 697,42 g. Perbedaan ini diduga karena perbedaan genetik dan kondisi lingkungan termasuk manajamen pemeliharaan (Subekti \& Arlina, 2011; Risnajati, 2014).

\section{Karakteristik Morfometrik}

Berdasarkan Tabel 2 terlihat bahwa dari semua ukuran-ukuran tubuh yang diukur terdapat perbedaan nyata $(\mathrm{P}<0,05)$ antara ayam kampung Super dengan ayam KUB pada LP, PK, TK, LK, Psa, TPu, PD, LS, Lti, PJK, dan JTP, sedangkan PP, PL, LL, PPu, LS, PS, dan Pti tidak berbeda nyata $(\mathrm{P}>0,05)$. Ukuran-ukuran tubuh antara ayam Super dengan ayam kampung berbeda nyata $(\mathrm{P}<0,05)$ pada seluruh ukuran tubuh yang di ukur. Ukuran-ukuran tubuh antara ayam KUB dengan ayam kampung berbeda nyata $(\mathrm{P}<0,05)$ pada $\mathrm{PP}$, TK, PL, Psa, PPu, PD, LD, PS, LS, Pti, Lti, PJK, sedangkan LP, PK, LK, LL, TPu, dan JTP tidak berbeda nyata $(P>0,05)$. Dari keseluruhan ukuranukuran tubuh yang diukur terlihat bahwa ukuran tubuh yang berbeda nyata $(\mathrm{P}<0,05)$ antara ayam kampung Super, ayam KUB dan ayam kampung adalah TK, Psa, PD, LS, Lti dan PJK yang artinya terdapat perbedaan penambahan ukuran tulang TK, Psa, PD, LS, Lti, dan PJK pada masing-masing galur ayam lokal. Perbedaan ukuran-ukuran tubuh pada penelitian ini diduga disebabkan oleh faktor genetik, karena faktor lingkungan sudah diupayakan seragam seperti diberi pakan yang sama dan dipelihara di lingkungan kandang yang sama. Hal ini sesuai dengan pendapat Hardjosubroto (1994) penampilan ukuran tubuh yang berbeda dapat dipengaruhi oleh faktor genetik serta lingkungan.

\section{Uji $\boldsymbol{T}^{2}$-Hotteling}

Uji $T^{2}$-Hotteling digunakan untuk mengetahui adanya kesamaan dan perbedaan ukuranukuran tubuh antara dua kelompok ternak. Uji $T^{2}$ Hotteling juga dapat membandingkan ukuran sifatsifat dua populasi secara bersamaan (Gaspersz, 2006). Hasil uji statistik $T^{2}$-Hotteling pada Tabel 3 menunjukkan bahwa ukuran-ukuran tubuh ayam 
kampung super berbeda sangat nyata $(\mathrm{P}<0,01)$

dengan ayam KUB maupun ayam kampung.

Tabel 2. Rataan ukuran-ukuran tubuh ayam kampung super, KUB dan ayam kampung

\begin{tabular}{|c|c|c|c|}
\hline Variabel & Ayam Super & Ayam KUB & Ayam Kampung \\
\hline $\mathrm{BB}(\mathrm{gr})$ & $837,98 \pm 68,97^{\mathrm{a}}$ & $713,15 \pm 66,75^{\mathrm{b}}$ & $605,53 \pm 80,01^{\mathrm{c}}$ \\
\hline $\mathrm{PP}(\mathrm{mm})$ & $30,88 \pm 2,58^{\mathrm{a}}$ & $28,92 \pm 1,42^{\mathrm{a}}$ & $27,08 \pm 1,65^{\mathrm{b}}$ \\
\hline $\mathrm{LP}(\mathrm{mm})$ & $6,36 \pm 0,91^{\mathrm{a}}$ & $5,59 \pm 0,44^{\mathrm{b}}$ & $5,33 \pm 0,72^{b}$ \\
\hline $\mathrm{PK}(\mathrm{mm})$ & $39,08 \pm 3,05^{\mathrm{a}}$ & $37,06 \pm 1,84^{\mathrm{b}}$ & $36,32 \pm 2,67^{b}$ \\
\hline TK (mm) & $30,74 \pm 2,17^{\mathrm{a}}$ & $27,54 \pm 1,94^{\mathrm{b}}$ & $26,07 \pm 1,27^{\mathrm{c}}$ \\
\hline $\mathrm{LK}(\mathrm{mm})$ & $101,98 \pm 6,29^{a}$ & $98,78 \pm 6,02^{\mathrm{b}}$ & $94,46 \pm 4,71^{b}$ \\
\hline PL (mm) & $107,39 \pm 6,77^{\mathrm{a}}$ & $106,37 \pm 6,57^{\mathrm{a}}$ & $96,49 \pm 6,36^{b}$ \\
\hline $\mathrm{LL}(\mathrm{mm})$ & $79,37 \pm 6,77^{\mathrm{a}}$ & $77,68 \pm 6,53^{\mathrm{ab}}$ & $74,95 \pm 5,35^{b}$ \\
\hline Psa (mm) & $170,08 \pm 8,49^{\mathrm{a}}$ & $166,07 \pm 6,67^{b}$ & $129,88 \pm 5,71^{\mathrm{c}}$ \\
\hline $\mathrm{PPu}(\mathrm{mm})$ & $167,20 \pm 8,05^{\mathrm{a}}$ & $165,29 \pm 6,01^{\mathrm{a}}$ & $160,93 \pm 6,27^{\mathrm{c}}$ \\
\hline $\mathrm{TPu}(\mathrm{mm})$ & $216,78 \pm 8,06^{\mathrm{a}}$ & $206,05 \pm 6,08^{b}$ & $203,80 \pm 6,31^{\mathrm{b}}$ \\
\hline PD (mm) & $106,10 \pm 6,98^{a}$ & $100,54 \pm 5,23^{b}$ & $95,08 \pm 6,34^{\mathrm{c}}$ \\
\hline $\mathrm{LD}(\mathrm{mm})$ & $49,79 \pm 5,51^{\mathrm{a}}$ & $47,47 \pm 4,37^{\mathrm{a}}$ & $41,25 \pm 5,41^{\mathrm{b}}$ \\
\hline PS (mm) & $64,96 \pm 7,37^{\mathrm{a}}$ & $62,76 \pm 6,25^{\mathrm{a}}$ & $58,39 \pm 6,46^{\mathrm{b}}$ \\
\hline $\mathrm{LS}(\mathrm{mm})$ & $41,31 \pm 3,85^{\mathrm{a}}$ & $36,44 \pm 2,38^{b}$ & $34,10 \pm 3,19^{c}$ \\
\hline PTi (mm) & $100,35 \pm 7,88^{\mathrm{a}}$ & $97,76 \pm 6,61^{\mathrm{a}}$ & $90,45 \pm 6,72^{b}$ \\
\hline LTi (mm) & $90,73 \pm 9,39^{a}$ & $78,66 \pm 6,16^{\mathrm{b}}$ & $72,66 \pm 6,03^{c}$ \\
\hline PJK (mm) & $54,78 \pm 5,42^{\mathrm{a}}$ & $52,11 \pm 4,49^{\mathrm{b}}$ & $48,26 \pm 5,13^{c}$ \\
\hline JTP (mm) & $13,98 \pm 0,82^{\mathrm{a}}$ & $13,60 \pm 0,58^{b}$ & $13,34 \pm 0,68^{b}$ \\
\hline
\end{tabular}

Keterangan:Superskrip huruf yang berbeda pada baris yang sama untuk masing-masing jenis ayam berarti berbeda nyata $(\mathrm{P}<0,05), \mathrm{PP}=$ Panjang Paruh, LP = Lebar Paruh, $\mathrm{PK}=$ Panjang Kepala, TK = Tinggi Kepala, LK = Lingkar Kepala, PL = Panjang Leher, LL = Lingkar Leher, PSa = Panjang Sayap, $\mathrm{PPu}=$ Panjang Punggung, $\mathrm{TPu}=$ Tinggi Punggung, $\mathrm{PD}=$ Panjang Dada, $\mathrm{LD}=$ Lebar Dada, $\mathrm{PS}=$ Panjang Shank, LS = Lingkar Shank, PTi = Panjang Tibia, LTi = Lingkar Tibia, PJK = Panjang Jari Ketiga, JTP = Jarak Tulang Pubis.

Demikian pula ukuran-ukuran tubuh ayam KUB berbeda sangat nyata $(\mathrm{P}<0,01)$ dengan ayam kampung. Perbedaan ukuran tubuh antara tiga galur ayam lokal tersebut diduga disebabkan oleh adanya perbedaan genetik, karena dalam penelitian ini kondisi lingkungan sudah diupayakan seragam seperti diberi pakan yang sama dan dipelihara di lingkungan kandang yang sama sehingga keragaman lingkungan hampir tidak ada. Hal ini sesuai dengan pendapat Hikmawaty et al. (2014) bahwa ukuran tubuh ternak dapat berbeda antara satu sama lain yang kemungkinan adanya perbedaan tersebut disebabkan potensi genetik, lokasi asal, serta sistem pemeliharaan dan perkawinan yang diterapkan. Perbedaan genetik ini diduga karena telah dilakukannya perbaikan mutu genetik melalui kawin silang pada ayam kampung Super dan melalui seleksi pada ayam KUB sehingga memiliki mutu genetik yang lebih baik dari pada ayam kampung. Menurut Urfa et al. (2017) ayam KUB merupakan ayam hasil seleksi ayam kampung asli Indonesia galur betina (female line) selama enam generasi. Ayam ini memiliki beberapa keunggulan, antara lain lebih tahan terhadap penyakit, pemberian pakan lebih efisien karena konsumsinya yang lebih sedikit, tingkat mortalitas rendah, serta produksi telur lebih tinggi dibanding ayam kampung lain.

Tabel 3. Hasil uji $T^{2}$-Hotteling ayam kampung super, KUB dan ayam kampung

\begin{tabular}{lrrrr}
\hline Ukuran Tubuh & Statistik T ${ }^{2}$-Hotteling & Nilai F & Nilai P & Kesimpulan \\
\hline KS-KUB & 689,48261 & 34,757868 & 0,00 & $* *$ \\
KS-K & 4744,17321 & 239,160995 & 0,00 & $* *$ \\
KUB-K & 7407,35207 & 373,415896 & 0,00 & $* *$
\end{tabular}

Keterangan: $\mathrm{KS}=$ kampung super, $\mathrm{KUB}=$ kampung unggul balitnak, $\mathrm{K}=$ kampung, ${ }^{* *}=$ Berbeda sangat nyata $(\mathrm{P}<0,01)$ 


\section{Analisis Komponen Utama}

Analisis komponen utama (AKU) merupakan salah satu cara untuk mengetahui diskriminan antara ukuran dan bentuk tubuh ternak ayam. Persamaan ukuran dan bentuk, keragaman total $(\mathrm{KT})$, dan nilai eigen $(\lambda)$ ayam Kampung Super, ayam KUB dan ayam Kampung disajikan pada Tabel 4.

Berdasarkan Tabel 4 terlihat bahwa PC1 ayam kampung super menunjukkan bahwa panjang tibia memiliki nilai 0,266 serta pada PC2 menunjukkan lebar dada memiliki nilai 0,737. Pada ayam KUB, PC1 menunjukkan bahwa panjang tibia memiliki nilai 0,263 serta PC2 menunjukkan panjang punggung memiliki nilai 0,391 , sedangkan pada ayam Kampung PC1 menunjukkan bahwa lebar dada memiliki nilai 0,250 serta PC2 menunjukkan panjang punggung memiliki nilai 0,451 . Variabel komponen utama ukuran ayam kampung super dan ayam KUB adalah panjang tibia. Artinya panjang tibia dapat dijadikan sebagai penciri ukuran tubuh pada ayam Kampung Super dan KUB karena memiliki kontribusi terbesar terhadap persamaan ukuran tubuh, sedangkan penciri ukuran tubuh pada ayam kampung adalah lebar dada. Sementara itu, variabel komponen utama bentuk tubuh ayam kampung super adalah lebar dada, sedangkan pada ayam kampung dan ayam KUB adalah panjang punggung. Hasil penelitian ini berbeda dengan penelitian Ashifudin et al. (2017) yang menyatakan bahwa penciri ukuran tubuh pada ayam kedu adalah panjang sayap, sedangkan penciri bentuk tubuhnya adalah panjang femur.

Perbedaan penciri ukuran dan bentuk tubuh pada masing-masing galur ayam diduga karena perbedaan genetik. Hal ini sesuai dengan pendapat Mahmudi et al. (2019), bahwa perbedaan ukuran maupun bentuk tubuh pada bangsa ternak kemungkinan disebabkan oleh adanya perbedaan faktor genetik. Penciri ukuran dan bentuk tubuh pada masing-masing galur ayam didapatkan melalui analisis komponen utama. Menurut Mariyandani et al. (2013) bahwa dalam analisis komponen utama, parameter fenotipik dapat digunakan untuk menentukan parameter morfometrik yang menunjukkan penanda bangsa dan disebut sebagai peubah pembeda bangsa. Bentuk tubuh sangat dipengaruhi oleh genetik, sedangkan ukuran tubuh selain dipengaruhi genetik juga dipengaruhi oleh lingkungan atau topografi daerah, tujuan pemeliharaan serta perawatan ayam.

Tabel 4. Persamaan ukuran dan bentuk tubuh ayam kampung super, KUB, dan ayam kampung

\begin{tabular}{|c|c|c|c|c|c|}
\hline Jenis & & & Persamaan & $\begin{array}{l}\mathrm{KT} \\
(\%)\end{array}$ & $\lambda$ \\
\hline \multirow{2}{*}{$\begin{array}{l}\text { Ayam } \\
\text { Kampung } \\
\text { Super }\end{array}$} & $\begin{array}{l}\text { Ukuran } \\
\text { Tubuh }\end{array}$ & $=$ & $\begin{array}{l}0,215 \mathrm{PP}+0,209 \mathrm{LP}+0,239 \mathrm{PK}+0,249 \mathrm{TK}+0,236 \mathrm{LK}+0,227 \mathrm{PL} \\
+0,239 \mathrm{LL}+0,252 \mathrm{PSa}+0,253 \mathrm{PPu}+0,246 \mathrm{TPu}+0,230 \mathrm{PD}+ \\
0,175 \mathrm{LD}+0,230 \mathrm{PS}+0,238 \mathrm{LS}+\mathbf{0 , 2 6 6} \mathbf{P T i}+0,252 \mathrm{LTi}+0,242 \\
\text { PJK + 0,230 JTP }\end{array}$ & 60,4 & 12,66 \\
\hline & $\begin{array}{l}\text { Bentuk } \\
\text { Tubuh }\end{array}$ & $=$ & $\begin{array}{l}-0,272 \mathrm{PP}-0,026 \mathrm{LP}-0,121 \mathrm{PK}+0,062 \mathrm{TK}-0,211 \mathrm{LK}+0,165 \mathrm{PL} \\
-0,225 \mathrm{LL}+0,012 \mathrm{PSa}-0,162 \mathrm{PPu}-0,139 \mathrm{TPu}+0,204 \mathrm{PD}+\mathbf{0 , 7 3 7} \\
\mathbf{L D}+0,127 \mathrm{PS}+0,113 \mathrm{LS}-0,137 \mathrm{PTi}-0,087 \mathrm{LTi}-0,105 \mathrm{PJK}+ \\
0,296 \mathrm{JTP}\end{array}$ & 5,0 & 9,00 \\
\hline \multirow{2}{*}{$\begin{array}{l}\text { Ayam } \\
\text { KUB }\end{array}$} & $\begin{array}{l}\text { Ukuran } \\
\text { Tubuh }\end{array}$ & $=$ & $\begin{array}{l}0,245 \mathrm{PP}+0,229 \mathrm{LP}+0,234 \mathrm{PK}+0,253 \mathrm{TK}+0,198 \mathrm{LK}+0,258 \mathrm{PL} \\
+0,242 \mathrm{LL}+0,256 \mathrm{PSa}+0,198 \mathrm{PPu}+0,239 \mathrm{TPu}+0,229 \mathrm{PD}+ \\
0,193 \mathrm{LD}+0,242 \mathrm{PS}+0,235 \mathrm{LS}+\mathbf{0 , 2 6 3} \mathbf{P T i}+0,241 \mathrm{LTi}+0,241 \\
\mathrm{PJK}+0,232 \mathrm{JTP}\end{array}$ & 67,6 & 12,17 \\
\hline & $\begin{array}{l}\text { Bentuk } \\
\text { Tubuh }\end{array}$ & $=$ & $\begin{array}{l}\text { 0,114 PP - 0,058 LP + 0,166 PK - 0,070 TK - 0,640 LK - 0,019 PL + } \\
0,302 \text { LL - 0,287 PSa + 0,391 PPu - 0,134 TPu + 0,281 PD - 0,139 } \\
\text { LD + 0,151 PS + 0,146 LS - 0,129 PTi - 0,168 LTi + 0,094 PJK - } \\
\text { 0,024 JTP }\end{array}$ & 5,0 & 0,90 \\
\hline \multirow{2}{*}{$\begin{array}{c}\text { Ayam } \\
\text { Kampung }\end{array}$} & $\begin{array}{l}\text { Ukuran } \\
\text { Tubuh }\end{array}$ & $=$ & $\begin{array}{l}0,235 \mathrm{PP}+0,245 \mathrm{LP}+0,240 \mathrm{PK}+0,235 \mathrm{TK}+0,248 \mathrm{LK}+0,248 \mathrm{PL} \\
+0,239 \mathrm{LL}+0,247 \mathrm{PSa}+0,214 \mathrm{PPu}+0,200 \mathrm{TPu}+0,232 \mathrm{PD}+ \\
\mathbf{0 , 2 5 0} \mathbf{L D}+0,232 \mathrm{PS}+0,245 \mathrm{LS}+0,216 \mathrm{PTi}+0,241 \mathrm{LTi}+0,228 \\
\mathrm{PJK}+0,243 \mathrm{JTP}\end{array}$ & 81,2 & 14,63 \\
\hline & $\begin{array}{l}\text { Bentuk } \\
\text { Tubuh }\end{array}$ & $=$ & $\begin{array}{l}\text { 0,226 PP + 0,119 LP + 0,076 PK - 0,279 TK - 0,227 LK - 0,056 PL + } \\
0,021 \mathrm{LL}-0,101 \mathrm{PSa}+\mathbf{0 , 4 5 1} \mathbf{P P u}-0,013 \mathrm{TPu}-0,456 \mathrm{PD}+0,045 \\
\mathrm{LD}-0,243 \mathrm{PS}+0,145 \mathrm{LS}+0,444 \mathrm{PTi}+0,158 \mathrm{LTi}+0,028 \mathrm{PJK}- \\
0,264 \mathrm{JTP}\end{array}$ & 3,0 & 0,54 \\
\hline
\end{tabular}

Keterangan: $\mathrm{PP}=$ Panjang Paruh, LP $=$ Lebar Paruh, PK = Panjang Kepala, TK = Tinggi Kepala, LK = Lingkar Kepala, PL = Panjang Leher, LL = Lingkar Leher, PSa = Panjang Sayap, $\mathrm{PTu}=$ Panjang Tubuh, TPu = Tinggi Punggung, $\mathrm{PD}=$ Panjang Dada, LD = Lebar Dada, PS = Panjang Shank, LS = Lingkar Shank, PTi = Panjang Tibia, LTi = Lingkar Tibia, PJK = Panjang Jari Ketiga, JTP = Jarak Tulang Pubis 


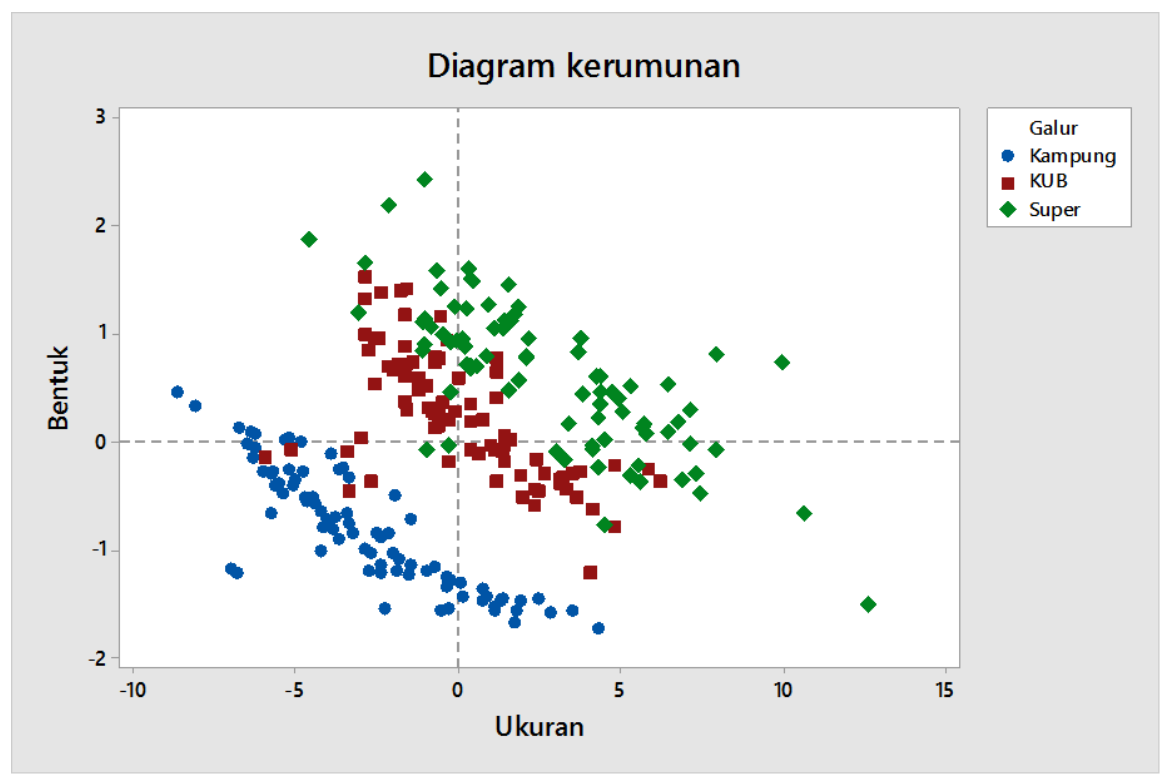

Gambar 1. Diagram kerumunan (sebaran) ayam lokal

Gambar 1 menunjukkan bahwa ayam kampung tidak memiliki penyebaran yang berhimpitan baik dengan ayam kampung super maupun dengan ayam KUB. Hal ini menunjukkan bahwa ayam kampung memiliki postur tubuh yang lebih kecil dibandingan dengan ayam kampung super dan ayam KUB. Selanjutnya ayam kampung super dan ayam KUB memiliki penyebaran yang berhimpitan, yang artinya ayam kampung super dan ayam KUB sama-sama memiliki postur tubuh yang relatif besar dibandingkan ayam kampung. Brahmantiyo et al. (2003) menyatakan bahwa ternak dapat memiliki genetik yang sama hubungannya dapat dilihat melalui peta penyebaran yang berhimpitan.

\section{KESIMPULAN}

Bobot badan dan morfometrik tertinggi ditemukan pada ayam kampung super, disusul ayam KUB dan ayam kampung. Ayam kampung super dan ayam KUB memiliki penciri ukuran tubuh (panjang tibia) yang berbeda dengan ayam kampung (lebar dada). Ayam kampung super memiliki penciri bentuk tubuh (lebar dada) yang berbeda dengan ayam KUB dan ayam kampung (panjang punggung).

\section{DAFTAR PUSTAKA}

Ashar, M.A. Pagala, \& T. Saili. 2016. Karakteristik fenotip kualitatif ayam kampung super. Jurnal Ilmu Peternakan Halu Oleo 1(1):1-9.

Ashifudin, M., E. Kurnianto, \& Sutopo. 2017. Karakteristik morfometrik ayam kedu jengger merah dan jengger hitam generasi pertama di satker ayam marontemanggung. Jurnal Ilmu Ternak 17(1):40-46.

Brahmantiyo, B., L H. Prasetyo, A.R. Setioko, \& R.H. Mulyono. 2003. Pendugaan jarak genetik dan faktor peubah pembeda galur itik (alabio, bali, khaki campbell, mojosari, dan pegagan) melalui analisis morfometrik. Jurnal Ilmu Ternak dan Veteriner 8(1):1-7.

Depison. 2010. Performans anak hasil persilangan induk sapi bali dengan beberapa bangsa pejantan di Kabupaten Batanghari Provinsi Jambi. Jurnal Agripet 10(1):37-41.

Djego, Y., J.N. Kihe, \& H.T. Pangestuti. 2019. Efek komposisi genotip dari ayam ras petelur, kate dan lokal sabu terhadap sifat-sifat pada bobot badan dan ukuran tubuh. Jurnal Nukleus Peternakan 6(1):20-25.

Eriko, Jatmiko, \& H. Nur. 2016. Pengaruh penggantian sebagian ransum komersial dengan dedak padi terhadap performa ayam kampung. Jurnal Peternakan Nusantara 2(1):27-33.

Gaspersz, V. 2006. Teknik Analisis dalam Penelitian Percobaan. Tarsito. Bandung.

Hardjosubroto, W. 1994. Aplikasi Pemuliabiakan Ternak di Lapangan. Gramedia. Jakarta. 
Hikmawaty, A. Gunawan, R.R. Noor, \& Jakaria. 2014. Identifikasi ukuran tubuh dan bentuk tubuh sapi bali di beberapa pusat pembibitan melalui pendekatan Analisis Komponen Utama. Jurnal Ilmu Produksi dan Teknologi Hasil Peternakan 2(1):231-237.

Hummairah, R. Hamdan, \& A.H. Daulay. 2016. Identifikasi morfometriks dan jarak genetik ayam kampung (Domesticated chicken) di Kabupaten Batubara. Jurnal Peternakan Integratif 3(3):329-343.

Mahmudi, R. Priyanto, \& Jakaria. 2019. Karakteristik morfometrik sapi aceh, sapi PO dan sapi bali berdasarkan analisis komponen utama (AKU). Jurnal Ilmu Produksi dan Teknologi Hasil Peternakan 7(1):35-40.

Mariyandani, H.N., D.D. Solihin, S. Sulandari, \& C. Sumantri. 2013. Keragaman fenotipik dan pendugaan jarak genetik pada ayam lokal dan ayam broiler menggunakan analisis morfologi. Jurnal Veteriner 14(4):475-484.

Permadi, A. N. N., E. Kurnianto, \& Sutiyono. 2020. Karakteristik morfometrik ayam kampung jantan dan betina di Desa Tirtomulyo Kecamatan Plantungan, Kabupaten Kendal, Jawa Tengah. Jurnal Peternakan Indonesia 22(1):11-20.

Rangkuti, N.A., Hamdan, \& A.H. Daulay. 2016. Identifikasi morfometriks dan jarak genetik ayam Kampung di Labuhanbatu Selatan. Jurnal Peternakan Integratif 3(1): 96-119.
Risnajati, D. 2014. Pengaruh jumlah ayam per induk buatan terhadap performan ayam strain isa brown periode starter. Jurnal Sains Peternakan 12(1):10-14. DOI: 10.20961/sainspet.v12i1.4866.

Sartika, T. 2013. Perbandingan morfometrik ukuran tubuh ayam KUB dan sentul melalui pendekatan analisis diskriminan. Seminar Nasional Teknologi Peternakan dan Veteriner. Puslitbang Peternakan. Medan, 3-4 september 2013. Hal: 561570.

Subekti, K \& F. Arlina.2011. Karakteristik genetik eksternal ayam kampung di Kecamatan Sungai Pagu Kabupaten Solok Selatan. Jurnal Ilmiah Ilmu-Ilmu Peternakan. XIV(2):74-86.

Suhardi, 2012. Identifikasi karakteristik morfologi ayam lokal khas dayak dari Kabupaten Berau, Kalimantan Timur. Jurnal Teknologi Pertanian 7(2):81-86.

Urfa, S., H. Indijani, \& W. Tanwiriah. 2017. Model kurva pertumbuhan ayam kampung unggul balitnak (KUB) umur 012 minggu. Jurnal Ilmu Ternak 17(1):5966. 
Putri et al./Jurnal Ilmu dan Teknologi Peternakan Tropis 7(3):256-263 